\title{
Marginálistípusok az ómagyar nyelvemlékkódexekben
}

1. Bevezetés, a kutatás szempontjai. A tanulmány az ómagyar nyelven íródott és fennmaradt 45 kódexünk lapszéli bejegyzéseinek, marginálisainak anyagát kívánja vázlatosan bemutatni és az anyag egyfajta rendszerezését adni. Mivel magyar nyelven nagyon kevés marginálisokkal foglalkozó publikáció jelent meg, angolszász példákat és csoportosításokat vettem alapul, majd szempontjaikat részben megtartva, de a gyüjtött anyag sajátosságaihoz igazítva dolgoztam ki a kategóriarendszert.

A fó rendező elv a szövegek tartalma és funkciója, mivel azt gondolom, hogy ezek sokkal többet árulnak el az anyag mibenlétéről, mint a pusztán helyalapú (hol jelennek meg marginálisok és azok milyenek) vagy alaki jellemzők szerinti csoportosítás. A többi szempont érvényesítése - kik, miért, mikor és milyen típusú bejegyzéseket hagytak hátra kódexeinkben - majd közelebb vihet doktori disszertációm fó kutatási kérdéseinek megválaszolásához: mit tudhatunk meg a marginálisok anyagán keresztül az olvasmánytörténet és nyelvtörténet felöl nézve, illetve a kódexek sorsáról, a közöttük lévő kapcsolatokról.

A tanulmány elején röviden bemutatom a marginálisok kutatási történetét, majd terminológiai kérdésekre és a saját gyüjtésemre, korpuszomra térek ki. Ezt követi az írás gerincét adó kategorizáció bemutatása példákkal illusztrálva, végül a továbbvezető kérdések megfogalmazása.

\section{A marginálisok kutatása}

2.1. Kutatástörténet és kutatási irányok. Jelen írás abba a viszonylag fiatal kutatási hagyományba illeszkedik, amely a könyvek margóira, üres helyeire beírt megjegyzéseket, marginálisokat gyüjti, csoportosítja és értelmezi. A tudományos margináliakutatás kezdetei az 1960-as évekre vezethetők vissza, amikor egymástól függetlenül többekben megerősödött a kéziratos jegyzetek iránti érdeklődés, és így a terület az 1990-es évek végére önállónak elismert tudományággá válthatott (ROSENTHAL 1998). A hetvenes évek elött mind a könyvtárosok, mind a könyvárusok előnyben részesítették a „tiszta” könyveket, és a marginálisokat tartalmazó köteteknek az értéke kisebb volt (kivéve, amelyekben valamilyen jelentős személy bejegyzése szerepelt; bővebben 1. TANSELLE 2011). Fontos kiemelni BERNHARD M. ROSENTHAL tevékenységét, aki a hatvanas években annotált könyveket kezdett gyüjteni és katalogizálni (RosENTHAL 1997). Részben az ő munkájának köszönhetően mára már több könyvtárban is figyelmet fordítanak arra, hogy a katalógusban jelezzék, ha egy kézirat vagy nyomtatott könyv tartalmaz annotációkat (CLEMENS-GRAHAM 2007: 43). Egy 1984-es cambridge-i kiállítás ${ }^{1}$ és en-

${ }^{1}$ Címe: Marks in Books, Shown and Explained: an Exhibition Devoted to Those Mysterious Traces Left in Books by Printers, Binders, Booksellers, Librarians, and Collectors - vagyis: Könyvek jelei, kiállítva magyarázatokkal: egy kiállítás a nyomdászok, könyvkötők, könyvárusok, könyvtárosok és gyüjtők által a könyvekben hagyott rejtélyes nyomoknak szentelve. (A szövegek fordítása minden esetben saját fordítás.) 
nek 1985-ben ROGER STODDARD gondozásában megjelent katalógusa (STODDARD 1985), valamint az ezeket követö tudományos diskurzus hívta fel a figyelmet arra, hogy mennyi nyom kerül a könyvekbe még a készítés elsődleges fázisának befejeződése után is, amelyek mind az adott kötet történetéről tanúskodnak. Az 1990es években a kutatók tekintete és érdeklődése a szövegtestről a margóra irányult, olyan céllal, hogy az ott található anyagok alapján egyének intellektuális világképét, szemléletét rekonstruálják. A margón található jegyzetek ugyanis a befogadást tükrözik: hogy mit jelentett a szöveg az olvasók számára, hogyan értelmezték őket.

A fontos esettanulmányok sorát (többek között John Dee-ről, William Drake-ről és Gabriel Harvey-ról) a 2000-es évek kezdetén a szintézis igénye követte, és sorra jelentek meg olyan müvek, amelyek azt a kérdést tették fel, hogy a marginália mint jelenség mit árul el az utókor számára, hogyan hasznosítható. Jelentek meg olyan munkák, amelyek egyes olvasók egy-egy könyvvel kapcsolatos élményét próbálják megragadni, munkák a nyomtatott marginálisokról és általános, elméleti értekezések is. A kiterjedt vizsgálatok ellenére még mindig vannak olyan területek, amelyek kevesebb figyelmet kaptak eddig, mint például a jogi és orvosi szövegek, valamint a kegyességi irodalom (CAMBERS 2010: 211-212). A marginálisok felértékelődése, tudományos elfogadottsága összefügg olyan új tudományterületek vagy szemléletmódok megjelenésével, mint az olvasmány- vagy mikrotörténeti kutatások.

A marginálisokhoz való hozzállás azonban - továbbra is - kettős, melyet jól szemléltet EAMON DUFFY megjegyzése, aki angol imakönyvek jegyzeteit és használati nyomait vizsgálta: „Ez az az anyag, a marginália, ami a vizsgálatom magvát adja. Azt kellene mondanunk, hogy az emberek, akiknek a könyveit vizsgálom, tönkretették azokat, úgy, hogy láttukra egy müvészettörténész a rosszallástól felszisszenne. Ám engem pontosan ez a vandalizmus érdekel, mert megragadhatók benne a használat nyomai, és a rejtély kulcsa, hogy egyáltalán milyen céllal használták az első tulajdonosok ezeket a könyveket" (DUFFY 2006: IX). A könyvekbe jegyzetelés egyesek szerint maguknak a könyveknek a megjelenésével egyidős, és az évszázadok során a különféle társadalom- és eszmetörténeti változások folyamatosan alakították széles skálán mozgó - és esetenként szélsőséges - megítélését. Jelen tanulmánynak ez nem tárgya (a témáról bővebben 1. azonban JACKSON 2001: 234-258; SHERMAN 2008: 151-178; illetve magyarul P. KoCSIS megj. e.).

Két nagy csoportját a marginálisoknak - amelyek a korai századoktól kezdve jelen vannak - már a kutatás elején érdemes elkülöníteni: az olvasóknak szánt és az olvasók által tett megjegyzéseket. Előbbieket a szerző vagy egy későbbi annotátor hozza létre, általában szisztematikusan, egy szöveget végigjegyzetelve, az utóbbiakat pedig a későbbi használók, akiket szintén jellemezhet szisztematikusság, de általában a bejegyzések tematikája tágabb és esetlegesebb. A két réteg más céllal és más logika alapján jön létre, így nem célszerủ őket azonos szempontok mentén vizsgálni és rendszerezni; ugyanakkor értelemszerüen hatnak egymásra, különösen előbbiek az utóbbiakra. Munkámban ezúttal az olvasók, használók által tett megjegyzésekkel foglalkozom.

2.2. Terminológiai és hatóköri kérdések. A könyvek lapjain olykor gyakrabban, máskor ritkábban feltünő utólagos bejegyzéseknek, jegyzeteknek, nyomoknak 
számos típusa van. Ezek általában más minőségúek, mint az önálló lapokra vagy jegyzetfüzetbe rögzített megjegyzések, mert a szöveg melletti pozíció alapvetően meghatározza fó jellemzöiket: elhelyezkedésük miatt az eredeti szöveg társaivá válnak (JACKSON 2001: 14). Ahogy említettem, a jelenség a korai századoktól kezdve megfigyelhető, s képviselőit sok-sok névvel illették a kortársak és a későbbi kutatók. Nehéz a különféle kutatási és megnevezési hagyományok körül rendet tenni, elkülöníteni és tisztázni, hogy mi a viszony a glossza, megjegyzés, komment, annotáció, firkák, posztillati és egyéb jelenségek és megnevezéseik között. A kérdést részletesen áttekinti SHERMAN (2008: 21-24), és arra jut, hogy a marginalia azért jól használható kifejezés, mert az adott bejegyzések helyét, terét, helyzetét (space) hangsúlyozza ki. Ez a hely, a margó pedig gazdag történeti, szociális, filozófiai és költészeti asszociációkat hordoz (SHERMAN 2008: 24).

A szóhasználattal kapcsolatban kérdéseket vet fel, hogy a magyar kutatásban a latinban többes számú marginalia 'dolgok a margón' helyenként (pl. folklorisztikai kiadványokban) használt forma, de ismert a nyomdászati terminológiának is részét képező - eredetileg melléknévi - egyes számú marginális alak is. Mivel itthon még a kérdéskörnek nem nagy az irodalma, ezért nincs igazán mihez igazodni, viszont fontosnak tartom azt is, hogy amennyiben a megnevezés nem teljesen idegen a magyar nyelvtől, illesszük a szóhasználatot a nemzetközi gyakorlathoz, ahol végülis jelen esetben az olvasmánytörténetnek köszönhetően ez a terminus terjedt el. Mivel pedig a magyar rendszerbe illik az egyes számú marginális is, én ezt az alakot használom.

Kutatásom azoknak a munkáknak a sorába illeszkedik, amelyek a marginálisokat olyan ,jegyzetek”-nek tekintik, ,amelyeket a margóra, vagy a könyv más üres részeire írtak" (SHERMAN 2008: XI), tehát ide tartoznak a jelentéstelennek tünő firkák, tollpróbák, az elözéklapok vagy üresen hagyott féllapok, lapok bármilyen tematikájú megjegyzései, valamint a könyvtári jelzetek, bejegyzések is. Ez a tágabb definíció is kirekeszti azonban az interlineáris glosszákat, amelyek hagyományosan egy-egy kifejezést fordítanak. A kódexek anyagát vizsgálva viszont kiderült, hogy esetenként a szövegközt tulajdonképpen margó funkcióban használják a bejegyzők, mert egyszerüen ott van hely, jellemzően éppen az olyan javítások esetében, amelyek a nyelvi változást tükrözhetik. (A későbbiekben valószínüleg ezt a csoportot tovább kell differenciálni, mert a szöveget a hangjelölés vagy a morfémák szintjén javító bejegyzők tevékenysége egy-egy kódex esetében önálló doktori disszertációk alapját adhatná, ugyanakkor a jelenség - globálisan mégis információértékủ.) Hasonlóképpen későbbi elvi döntést igényel majd, hogy marginálisoknak számítanak-e az akár többlapos 16-17. századi imádságok, hoszszabb szövegrészletek, amelyeket nem egy-egy féllapra, hanem a kéziratok akkor még üresen hagyott lapjaira jegyeztek be, a korabeli használók igényeihez igazítva ezzel a kötetek tartalmát. Mivel mindezt az anyag és a problémakörök mélyebb ismerete után kívánom eldönteni, egyelöre gyüjtök mindent, amit nem a könyvet készítő scriptor vagy scriptorok írtak. Így rendkívül heterogén anyag jön létre, amely magába foglal mindent a 16. században bejegyzett imádságoktól a 19-20. századi könyvtárosi bejegyzésekig. 
3. A vizsgált korpusz és rendszerezési szempontok. Ahogy már említettem, vizsgálatom tárgyát egy zárt korpusz: az ómagyar nyelvemlékkódexek csoportja adja. Ebből következik, hogy a beírók természetesen más, latin nyelvü, korabeli kódexek lapjain, esetleg levélszerzőkként is feltünhetnek, ezek feltárása azonban - bár kétségtelenül hasznos lenne - átláthatatlanná tenné a kutatást. A kézazonosítás helyett így elsősorban a bejegyzések tartalmára és a kezek esetleges azonosságára koncentrálok, hogy a kódexek történetéhez tudhassunk meg adatokat. A gyüjtés során a 45 kódex nagy felbontású digitális másolataival vagy az eredetikkel dolgoztam, digitálisan tárolom az elérhető marginálisok képeit, amelyeknek a betủ szerinti átírását egyéb járulékos információkkal (bejegyzés helye, iránya, nyelve, tinta színe, kiváltó szövegrészlet, bejegyző személye stb.) igyekszem ellátni. Így az anyag az említett szempontok szerint rendezhető és elemezhető. A feldolgozás eredményeként egy megközelítőleg 800 marginálist és adatait tartalmazó gyüjtemény áll a rendelkezésünkre, amelynek pontos adatszáma a már említett interlineáris és szövegközi javítások miatt nem határozható meg pontosan. A vizsgálat újdonsága egyrészt az, hogy összegyüjtve, egységben tárgyalja a kódexek fennmaradt későbbi bejegyzéseit, amelyekkel kapcsolatban az eddigi hozzáállást jól mutatja, hogy a kódexkiadásokban sok esetben meg sem említik őket (természetesen vannak kivételek). A kutatás újszerüségét másrészt az adja, hogy a marginálisokhoz elsősorban nem az irodalom- és befogadástörténet, hanem a kódextörténet és a nyelvtörténet felöl közelít.

3.1. Az angolszász kategorizációk szempontjai. Az angolszász kategorizációk közül - amelyek az olvasók által írt marginálisokra vonatkoznak - hármat szeretnék megemlíteni, amelyeket különböző szempontok miatt a magam számára is hasznosnak tartok.

A legáltalánosabb, elsősorban az elhelyezkedésre koncentráló felosztás HEATHER JACKSON rendszere, aki háromszáz évnyi időszak angol nyelvü könyveinek áttekintése után arra a megállapításra jutott, hogy időben nem változik az, hogy bizonyos típusú jegyzetek a könyvek mely részében szerepelnek, és ezt magának a könyvnek a formája határozza meg (JACKSON 2001: 41). Ennek szellemében állította fel tipológiáját (JACKSON 2001: 19-41), amelynek a rendező elve az, hogy egyes részek milyen jegyzeteket, bejegyzéstípusokat vonzanak, és hogy azok általában milyenek. Azért ismertetem az ő munkáját részletesebben, mert nagyon jó áttekintését adja a marginálisoknak általánosságban.

Az első lapok tipikus bejegyzései a t u lajd o n o s i be j e gy zé s e k, amelyek íródhatnak ceruzával, tollal, vagy szerepelhetnek ex libris formájában. Gyakoriak itt (meg a könyv végében, illetve bárhol, ahol üres hely van) a g y e r e k firkák és raj zok; láthatunk olyat, hogy valaki, miután le tudja írni a nevét, teleírkálja vele a könyvet. Ezeket a lapokat szokás fi r k a p a p ír nak, jegyzetlapnak is használni, bármilyen témában. Felnőttek általában az első üres lapra, ha van ilyen, vagy a címoldalra szokták beírni a nevüket, címüket, beszerzés dátumát és olykor a forrását is. Ezek szerepelhetnek öröklődő, ritmusos versikékben. Gyakori, és középkori hagyományokra visszavezethető, hogy beírnak a könyvbe egy figye $1 \mathrm{mez}$ e té st (eredetileg átkot), hogy ne akarja senki ellopni. Szintén a könyvek elejére szoktak bemásolni más forrásokra vonatkozó hi vatk o zá s o - 
$\mathrm{k}$ at vagy csak információkat, amelyek hasznosak lehetnek az olvasáshoz. Előfordul, hogy az olvasók a könyv elején (vagy a végén) összegzik a v é le m é n y üket, re fle x i ó ikat a könyvvel kapcsolatban, ami saját maguknak lehet emlékeztetö, vagy másoknak adhat információt.

A szövegtestben különböző típusú helyekhez különböző típusú és funkciójú szövegek kapcsolódnak. A felső margókon gyakoriak a nyomtatott vagy az olvasók által írt „, f e j e z e t c í m e k”, címek, kulcsszavak. A lapok alsó margóin szerepelhetnek oldals zá mok, vagy maguk a jegyzetelők is mímelhetik, hogy lá bj e g y ze te k et írnak. Vannak olyanok, akik csak és kizárólag az alsó margóra jegyzetelnek, mert ha keresnek valamit, elég azt átpörgetni, míg mások csak akkor használják az alsó margót, ha nem férnek el az oldalsón, és „lefolynak”. A sorközöket a jegyzetelők nem használják, az szigorúan és hagyományosan az interlineáris glosszák helye, és a szóról szóra tükörfordított szövegeké. A leggyakoribb hely, ahova jegyzetelnek, az oldalsó margó. A legesleggyakoribb és legalapvetőbb nyomok egy könyvben az a láhúzások, függőleges vonalak a sorok mellett, felkiáltó - és kérdőjelek, ikszek, pipák stb. Vannak olyan jegyzetelők, akik önálló jelrendszert dolgoznak ki, és azt használják. A következő szint, amikor valaki rövid szavakat vagy kifejezéseket ír, majd őket követik a hosszasan jegyzetelők. A bőbeszédủek, ha kicsi a margó, átfolyhatnak alulra, másik lapra, vagy elfordítják a könyvet és függőlegesen írnak.

A könyv végén a leggyakoribb az ált a lá n o s véle mén ye $k$, be n y omá s o k kifejtése. Az utolsó lapok az olvasók által készített tárg y mu ta tó knak adnak helyet. Ez egy fontos rész, itt gyüjtik a címeket, kulcsszavakat és melléjük az oldalszámokat. Vannak, akik csak az oldalszámokat írják ki, de az nem túl informatív. Az oldalszámok sorrendje tükre lehet az olvasási módnak: mutatja, hogy az olvasó a könyv elejétől haladt a végéig, vagy esetleges sorrendben olvasta egyes részeit. Ritka, hogy átfogalmazzák a könyv szövegezését és a mutatóban saját szavakat használjanak (JACKSON 2001: 19-41).

WILLIAM SHERMAN a reneszánsz olvasók marginálisait elemző könyvében másoktól idéz egy rövidebb és egy részletesebb kategorizációt. Az első ELAINE E. WHITAKERtől származik, aki szerint egyébként minden marginális egyedi, de nagyjából a következő kategóriákba sorolhatók (WHITAKER 1994: 235, idézi SHERMAN 2008: 16):

1. Szerkesztés (Editing):

a) cenzúrázás (Censorship),

b) megerősítés (Affirmation).

2. Interakció

a) kegyességi használat (Devotional Use),

b) társadalomkritika (Social Critique).

3. Elkerülés, közönyösség (Avoidance)

a) firkálás (Doodling),

b) álmodozás (Daydreaming).

WHITAKER kategorizációja, amely a szöveghez való viszony alapján készült, nagyon alapvető, de szükszavú rendszert állít fel, így a finomabb differenciálásra jobb példa a CARL J. GRINDLEY által készített többszintü tipológia, amely a jegy- 
zetek és jelek minden típusát magába foglalja (GRINDLEY 2001: 77-91). Ö is három fö kategória - amelyeket további alkategóriákra oszt - mentén rendezi az anyagot: 1. jelek, amelyek nem kapcsolhatók szöveghez; 2 . jegyzetek, amelyek az adott könyvhöz, szöveghez csak érintőlegesen kapcsolódnak; és 3. marginálisok, amelyek az olvasók egy adott szöveghez kapcsolódó reakcióit tartalmazzák. A forrásanyagok sokfélesége és különbözősége miatt természetesen egyikőjük rendszere sem alkalmazható egy az egyben a kódexek marginálisaira, a főszöveghez való viszony szerinti osztályozást azonban részben én is megtartottam.

3.2. A magyar kategorizáció kialakításának és közlésének alapelvei. A továbbiakban egy a magyar anyag belső logikája mentén kialakított rendszert ismertetek. A kategorizáció alapvető rendező elve a szövegek tartalma, a kategóriák pedig a használat, funkció, a feltételezhető lejegyzői szándék nyomán alakultak ki. Ugyan a következőkben megpróbáltam minden szöveget besorolni, természetesen sok esetben a tartalom és a funkciók is keveredhetnek. Gyakori például, hogy valaki egy egyébként más információt is tartalmazó bejegyzés végére a dátumot is odaírja. Ez datálás is, de a bejegyző elsődleges célja valószínűleg nem a datálás volt. A csoportosítás kialakításakor a kategóriák felállítása volt a cél, de a későbbiekben természetesen szükséges a kategóriák vegyülését, együttes jelentkezését is vizsgálni.

Fontosnak tartom megemlíteni, hogy a kategorizáció nem cél önmagában - azt hivatott szolgálni és segíteni, hogy a rendkívül heterogén anyagot rendezettebben lássuk, és erről az alapról kiindulva egyrészt másfajta típusú és szempontú megállapításokat tehessünk, másrészt új kutatási kérdések irányába indulhassunk el. A bejegyzések jellege tekintetében alapvetően két nagy korszak különíthető el: a szerzetesrendek 1782-es feloszlatása előtti „,vallásos” használat időszaka, illetve a későbbi, 19. századi, a nyelvemlékgyüjtés idejében megjelenő tudományos érdeklődés szakasza. Ez a kép azonban túlságosan elnagyolt: a kolostori használat időszakából is maradtak ránk bőven világi és tudományosabb jellegü bejegyzések, és akár a későbbi századokban is használhatta valaki eredeti céljával a köteteteket. Mégis, a bejegyzések többségének születése szempontjából nagyjából ezzel a két korszakkal számolhatunk.

A kategóriák számossága nagyon eltérő, bizonyos esetekben azonban - tekintettel az anyag töredékességére és esetlegességére - indokoltnak éreztem akár egy adatot is önálló kategóriába sorolni, különösen, ha egyébként külföldi példák is találhatók rá. Mivel sok határeset, összefonódás és adott esetben kétes adat van, jelen írásban a számadatok közlésétől eltekintek. Külön problémát és kérdéskört jelent az adatok személyhez és időponthoz kötése, így ha szükséges és információértékkel bír, az íráskép alapján nagyjából meghatározható századot adom csak meg.

A marginálisok közlésénél fontos elv, hogy - amennyiben megállapítható - a kiváltó főszöveget is közölni kell (KERBY-FULTON 2012: 210). Ettől terjedelmi okok miatt általában eltekintek, és csak akkor közlöm a főszöveget, ha anélkül a marginális nem lenne értelmezhető. A kódexek szövegének közlésekor a Régi Magyar Kódexek sorozat átiratait követem, a marginálisok esetében azonban lehet eltérés a kötetek és a saját átirataim között. Mivel a margó sok esetben keskeny, nagyon sok szöveg több sorba tagoltan szerepel a kódexekben. A sortörések jelölése azonban szétdarabolja a szövegeket, jelen munkában pedig a szövegek tartalma kerül előtérbe, így a sortöréseket csak szükség esetén jelölöm. 
4. A magyar kódexek marginálisainak tartalmi-funkcionális felosztása. Az anyagot áttekintve hat fö kategóriát határoztam meg, amelyek bemutatása, jellemzése és példákkal történő illusztrálása következik a továbbiakban. A hat kategória: 1. Tulajdonosi és a kézirat eredetére, sorsára vonatkozó bejegyzések. 2. A szöveghez való praktikus, gyakorlati viszonyulást tükröző bejegyzések. 3. A szöveg egyes elemeit kiemelö bejegyzések. 4. Az olvasási élmény kommentálása során keletkezett megjegyzések. 5. A kézirat vagy annak tartalma előidézte, de ahhoz csak lazán kapcsolódó bejegyzések. 6. A szövegek tartalmától független bejegyzések.

4.1. Tulajdonosi és a kézirat eredetére, sorsára vonatkozó bejegyzések. A kategória olyan szövegeket és bejegyzéseket tartalmaz, amely a tulajdonosok személyére és a kódexek sorsára közvetve vagy közvetlenül utalnak. Ezek nagyon sokfélék és különböző hosszúságúak lehetnek, az ex librisektől és egyszerüen beírt nevektől kezdve a hosszasabb proveniencia-bejegyzésekig, amelyek egy-egy konventhez vagy intézményhez kötik a kéziratokat. A jelzetek, raktári számok, bélyegzők különféle korokból származhatnak, és sokszor kódextörténeti vagy a kódexek közötti kapcsolatokkal összefüggő kérdéseket oldhatnak meg vagy vethetnek fel.

a) A kódexek tulajdonosaitól származnak a különféle poss ess or b e j e g y z é s e k. Ezek általában a kötéstáblán vagy az első lapon szerepelnek, és rendszerint csak a tulajdonosok nevét tartalmazzák; esetenként kiegészülhetnek lopás vagy elvétel elleni figyelmeztetéssel, datálással. A kódexekben fennmaradt adatok széles időskálán mozognak, a 16. századtól a 19. századig tudunk példákat idézni. Vannak köztük intézmények (pl. Conuentus Nimet Uyuarieinsis 1661 KeszthK. kötéstábla; Ez a konuf Testeletes becoletes Conuetti Melet egi apaca Irta Mater Anna Franciska harmic Noci ezdedos koraban holt megh die 18 Juli Anno 16502 [!] - ÉrsK. kötéstábla), és jobban vagy kevésbé ismert személyek nevei, pl. Iohannis Alberti Widmanstetterii (MünchK. 8r), Balthasarius de Batthyan (KeszthK. 4r), Martinus Lazar (LázK. előzéklap). A possessor-bejegyzésekhez hasonló, de nem egyértelműen birtoklásra, inkább csak az olvasás tényére utaló bejegyzések, amikor valaki nem a teljes nevét jegyzi be a könyvbe; pl. Soror Kata (ThewrK. 169), barbara (JordK. 55r), Vrsula Barbara (GömK. 11).

b) A tulajdonlás jelzésének a név beírásánál egy fokkal hivatalosabb formája, ha valaki az ex 1 ib r i sét ragasztja a könyvbe. Az ex libris egy-egy személyhez (olykor intézményhez) köthető, általában nyomdai úton előállított kisebb méretű papírlap valamilyen azonosító címerrel, jelképpel, névvel, esetleg mottóval, amelyet a tulajdonosok a belső kötéstáblára ragasztanak. A kódexek közül háromban találkozunk ex librissel: a Domonkos-kódexben Gabriel Zerdahelyi 1800-ból származó ex librise szerepel, a Kulcsár-kódexben datálatlanul Johannis Seth komáromi orvosé, a Müncheni kódexben pedig a Bajor Udvari Könyvtáré.

c) Hasonló célt látnak el magánszemélyek vagy intézmények b él y e g z ő i . Ezek a birtokosok pecséthasználatának ismeretében információkat nyújthatnak arról is, hogy mikor került a kézirat egyik tulajdonostól a másikhoz. A kódexek kapcsán legtöbbször előforduló pecsétek a könyvgyüjtő Jankovich Miklóstól származnak, akinek többféle pecsétje is volt (pl. HorvK., KazK., KrisztL. stb.), de találkozunk például a Székely Nemzeti Múzeum és Csereyné Zathuretzky Emília bélyegzőivel az Apor-kódexben. 
d) A bélyegzők mellett a különféle korokban a könyvekbe került jelzet e k - amennyiben helyhez és időhöz tudjuk kötni őket - segíthetnek a kódexek vándorlásának, későbbi útjának feltárásában. Gyakoriak az újabb kori, a nemzeti könyvtárakban általában grafittal bejegyzett jelzetek (pl. M. Nyelvemlék 74 . $F M 1 / 503$. - KeszthK. elözék), de találunk kevésbé egyértelmủeket is a korábbi századokból: 15. VI. 6 III. 76 és 1839/503 a Döbrentei-kódexben, R. 524 (DebrK. előzéklap), Theolog $B$ (BécsiK. 1).

e) A kategória másik nagy csoportját a proven i encia-beje gy zés ek alkotják. Ezek közé tartoznak a hosszabb, általában intézményhez tartozást rögzítő és a hozzájuk kerülés mikéntjéről tájékoztató szövegek. Példa: Post longam curiositatem Āo 1810 detexi librum hunc scriptum esse in utilitatem Monatis Judithae Nwÿthody a Fratre Andrea Nwythodÿ Fransiscano Anno 1526 vide pag. 60. 61. Daniel Fantsali Parochus Gyergyo Sz Miklos (SzékK. kötéstábla). Némely kódexek (pl. KeszthK.) alapján úgy tünik, mintha egy ilyen bejegyzés tulajdonoscserékkor vonzaná a következőt. További példák: NagyszK. kötés, KeszthK. előzéklapok. Ide tartozónak vettem a nemzeti könyvtárakba kerüléskor a kódexek előzéklapjaira jegyzett dokumentációkat is. Például: E’ kézirat 1787-ben Peer Jakab piarista áldozár 's Pozsonban a'történelem tanáraé volt. Holta után Jankowich Miklós vette-meg, kinek gyüjteményéböl 1852-ki Januar. 20-kán hozatott-át a'Széchényi-országos könyvtárba, 's itt újonnan beköttetett, meg-tartatván minden lap a régi kötésböl, mellyen valamelly érdeket gerjeszthetö iromány volt olvasható. Emlékezik e' kéziratról Révay (Antiquit.) és Horvát István 1835. Tudom. Gyüjt. V. füzet 106-107. lap. Mátray Gábor mp. (PeerK. elözéklap; hasonlókat 1. SimK. kötés, CzechK., GuaryK., KrisztL. előzék). - Nem alkotnak önálló kategóriát, mert általában valami máshoz kapcsolódva jelentkeznek, de nagyon fontos információkat hordoznak az egyes bejegyzések datálása i, pl. Anno domini 1.6.5.9. Renoatus ést libélus isté. ab. S. G. magistro Hidisiensi (DebrK. 624); Ā̄. $\overline{93} 20$ Julÿ. (KazK. elözék).

4.2. A szöveghez való praktikus, gyakorlati viszonyulást tükröző bejegyzések. Ide olyan bejegyzések tartoznak, amelyeket a kódexek azon használói írtak, akik a könyvet láthatóan eredeti rendeltetésével, (fel)olvasásra használták, esetleg másolták vagy másoltatták. Bejegyzéseikkel a szöveget saját igényeikhez igazították, vagy a saját maguk későbbi, illetve más olvasók tájékozódását igyekeztek segíteni a kötetekben.

a) A csoport egyedülálló példája az Apor-kódexben fellelhető z s o l t á r c í m e k sorozata. Ez egy összefüggő marginálissorozat, amelyet a kódex zsoltáraihoz a lapszélekre feltehetően az 1530-as években másolt be egy későbbi használó. A bejegyzések a szövegek egyfajta értelmezés szerinti tartalmát és javasolt használatát adják meg. Például: Afaph halat ad yftennek hogÿ az ÿokot kýk az cryftwfth fogattak / olttalmazza / es az gonozokat meg feddy (AporK. 72, 74. zsoltár); Intÿ az egÿhazý nepeketh az profeta hogÿ hÿwen zolgallyanak az wrnak (AporK. 145, 142. zsoltár). (A kérdéskörről részletesebben 1. P. KoCSIS 2015, 2016.)

b) A szövegek jól olvashatóságát, folyamatosságának fenntartását segítik azok a s zövegki egészítés ek, amelyek olyan esetekben fordulnak elö, amikor az eredeti szövegben valamilyen, a szövegértést zavaró hiányt tapasztalt az olvasó. 
A Bod-kódex egy helyén például egy iniciálénak kihagyott helyen toldott be valaki egy szót: Regenten Isten eǵ zent Iambornak, ill'en rettenetes dolgot mutata $(\text { BodK. } 31)^{2}$. A Nádor-kódex egy későbbi olvasója jellel a helyére utalva a margón egészítette ki a szöveget: Ki menven kedeg az apat / Le esec o elotte az ifÿv Konyoroghuén az Apáturnak hogj fogadná bé eöket az kalastromban ÿmadsagot teven / le úlenec (NádK. 418), a Czech-kódexben pedig egy laphiány miatti két csonka imát egy olvasó lapalji bejegyzéssel, kiegészítéssel kötött össze: ees te ÿrgalmassaagodnak kebeleeben | tarcz meg en- || gomet ees en meg halaasomnak oraaÿat (CzechK. 122-123). Kisebb kiegészítések találhatók olyankor is, amikor valaki a hiányzó iniciálékat pótolja a számukra üresen hagyott helyeken (pl. BodK. 27, DebrK. 396, KeszthK. 19; stb.).

c) Számos további altípusba sorolhatók a n y elvi javítások. Több kódex esetében is előfordul, hogy egy-egy későbbi olvasó szisztematikusan igazít szövegeket a saját nyelvi ízlésének, nyelvállapotának vagy helyesírásának megfelelően. Ezek elemzése túlságosan hosszadalmas lenne, másrészt a példák idetartozását, hatókörét is tisztázni kell majd a továbbiakban, viszont a tömeges javítások egy-egy szövegegységben arra utalhatnak, hogy azt az adott szöveget biztosan olvasták. Ilyenek például a Sophia asszonyról szóló rész az ÉrdyK. 301-306. lapjain, vagy Szent Eugénia élete a TihK. 293. lapjával kezdődően. A morfológiai szintủ javítások (pl. sÿralomban MargL. 163) nyelvtörténeti változásokra utalhatnak, a szószintüek pedig szintén nyelvi (ízlés)változást tükrözhetnek, esetleg más nyelvjárású nyelvhasználót: holual $\rightarrow$ reggel, monnofelnek $\rightarrow$ minden (JókK. 5, 12 ), zynten feÿer $\rightarrow$ Tiszta feÿer, ydegokel $\rightarrow$ Szejakal (ÉrsK. 68, 72), ikomnek $\rightarrow$ Nagi Aniamnak, onokad $\rightarrow$ öczed (KazK. 54, 57). (A kérdéshez 1. HAADER 2005, 2009.) A nyelvi javítások egy speciális esete a törlés, ami általában kihúzásként valósul meg; ilyenkor az olvasó nem hozzátesz, hanem elvesz a szövegböl.

d) A praktikus, kolostori használat nyomai azok a bejegyzések, amelyek u ta sí tá s o k a t adnak egyrészt a (fel)olvasóknak, hogy az egyes szakaszokat mikor, hol, kinek kell olvasnia: [Mindenszentek napján ...] Kel olvasni (CornK. 92v), Eböl Virag Vaszarnap estue Nagi Czütör estue oluasznak (WeszprK. borító), Ez veghe az adventÿ zolozmanak (FestK. 311); másrészt kijelölhetnek bizonyos másolandó szakaszokat: ez az leg elso Pelda az kit kel irn [...], it vége vagyon (CornK. 212r, 216v), ezis hoza ualo ezt is Le kel irnya (PéldK. 43). Egyes példák esetében nem dönthetö el egyértelműen, hogy a megjegyzés a felolvasónak, egy jövendő másolónak, esetleg mindkettőjüknek szól: fordécs két levelet - It keszd el (ÉrsK. 424, 429).

e) A kéziratoknak az aktív, rendeltetésszerü használatáról tanúskodnak a t a r t a lo mj e g y zékek, amelyek sokszor nem különböznek a maitól: a szövegek címét vagy kezdősorát tartalmazzák a fólió vagy oldalszám megadásával. Ehhez általában az is szükséges, hogy a scriptor, egy korábbi bejegyző vagy a tartalomjegyzék készítője paginaszámokkal lássa el a kéziratot. Hosszabb tartalomjegyzékeket találhatunk például a következő helyeken: DomK. 339-342, LázK. 191-192, FestK. 417-418. Kiemelendő az ún. „klarissza kéz” tevékenysége (LÁzS 1981;

${ }^{2}$ Az idézetek esetében a félkövér kiemelés a kódexkiadások gyakorlatától eltérően nem a rubrumozást jelöli (amit a szövegek idézésekor nem különböztetek meg), hanem a marginálist, vagy a változtatott nyelvi egységet és a marginálist. 
PUSZTAI-MADAS 1994: 10), aki - vagy akik, a kérdés tisztázandó - több kódex lapszéleire és kötéstábláira jegyzetel, s valószínüleg egy priorissza vagy könyvtáros lehetett. Bejegyzéseiből példák: Eben az Könuben vagion $\mid S z$ Eufrusina Elete [...] | [...] Sz Apoloniaÿ | Sz Aduigai | [...] Sz Adoriani $\mid$ Sz Sofiay $\mid$ Sz Atlexiusi $\mid$ Sz Maria Egip | sziakaÿ (NádK. kötés); Eben az könibe vagion | Sz Barlam es $\mathrm{Sz}$ Iosafat elete | Sz Vrsolai | Sz Alexiussü (KazK. elözék); Szent Christinä̈ | Nagi Boldog Aszoni | Az Szerzetes eletrūl ualo | Iras (HorvK. elveszett elözéklap).

f) A kódexek szövegeihez jellemzően nem tartoztak címek, esetleg rubrikák (általában piros tintával írt hosszabb témamegjelölés a szöveg előtt), így a legtöbb cím a dá s, cím la p a későbbi, 19. századi szakaszban keletkezett, de találkozunk néhánnyal a korábbi századokból is. Pl. ORATIONES BEATAE BRIGIDAE VIRGINIS $\cdot X V \cdot$ ante'magmem dñi nrì Iesu x $\bar{p} \bar{i}$ crucifixi in dies deuotissime dicendae ORATIO PRIMA (GömK. előzék), Az léolkÿ ismerettül valo zamuetelnek Formaia Soror Justinanak (ThewrK. 169).

g) A szövegekkel való tudós, jellemzően már 18-19. századi foglalkozás hozott létre olyan megjegyzéseket, amelyek a kötet e k szövegének vagy lapsorrendjének álla p o tár a vonatkoznak. Kutatók, tulajdonosok, könyvtárosok próbálták a kéziratok levélsorrendjét, hiányait rögzíteni, ezért ezeket általában már személyhez is tudjuk kötni. A megjegyzések különösen is fontosak, ha azóta a kódexet restaurálták, de a lapsorrend esetleges változását nem jegyezték fel. Példák: Vide folium 2dum superius (DebrK. 4, Sinai Miklós bejegyzése); Itt fogyatkozik. W. J. Miklós (KrisztL. 46, Jankowich Miklós); folyt. és végét l. p. 429 és 30. (ÉrsK. 424, Volf György).

4.3. A szöveg egyes elemeit kiemelő bejegyzések. Tipikusan a margóra írt, a latin hagyományokra visszavezethető csoport, amelynek angolszász példái is vannak bőven (COPELAND 1991: 82-90; KERBY-FULTON 1999). Esetenként maguk a scriptorok is készítettek ilyet, vagy később az annotátorok jegyezték be, és hasonló módon hoztak létre emlékezést segító jegyzetanyagot a humanista tudósok is (JACKSON 2001: 53-56). A csoport azon elemeiből közlök a következőkben példákat, amelyeket a későbbi bejegyzők hagytak hátra a kódexek lapjain. Mivel ezek a főszövegtől függetlenül nem értelmezhetők, ezeket is feltüntetem velük együtt.

\begin{tabular}{|c|c|c|}
\hline Marginális & Főszöveg & Forrás \\
\hline \multicolumn{3}{|c|}{ Locus kiemelése: } \\
\hline Sap 45 & $\begin{array}{l}\text {...vg mondattatic bolc kọnóuenec neguenọd } \\
\text { resceben o halal mel igọn keserv́ atte } \\
\text { emlekezetọd... }\end{array}$ & SzékK. 254 \\
\hline$[\ldots] \overline{p s} C x i j$ & $\begin{array}{l}\text { Azonrol emlekózik zent dauid proffeta ees ps } \\
\text { clviij... }\end{array}$ & ÉrdyK. 54 \\
\hline \multicolumn{3}{|c|}{ Szereplő kiemelése: } \\
\hline Ezechias Rex & $\begin{array}{l}\text {... Micoron az minden hato isten Isaiast kilde } \\
\text { ezechias kÿral'hoz... }\end{array}$ & DebrK. 369 \\
\hline
\end{tabular}




\begin{tabular}{|c|c|c|}
\hline Maria magdalena & $\begin{array}{l}\text { Mikoron azert ekeppen mezitelen allana oly mint } \\
\text { rezketue a hidegert es az sok sebokert... }\end{array}$ & WeszprK. 102 \\
\hline \multicolumn{3}{|l|}{ Szerző kiemelése: } \\
\hline De Homer [us]. & $\begin{array}{l}\text {...az omerus vers zerzọ mester ez alexandert } \\
\text { Iouisnac a felseges istēnec fianac moga... }\end{array}$ & SzékK. 242 \\
\hline \multicolumn{3}{|c|}{ Szövegtagolás hangsúlyozása: } \\
\hline $2 d o$ & Masodzer igon soc ahalalnac hele... & SzékK. 246 \\
\hline 3. & A harmadik tanusag... & DebrK. 33 \\
\hline \multicolumn{3}{|c|}{ Tartalom megjelölése: } \\
\hline $\begin{array}{l}\text { de sacris } \\
\text { stigmatibus: }\end{array}$ & $\begin{array}{l}\text { Ugÿ vagion meg irua hogi mikoron auerna hegien } \\
\text { bwÿtwlne zent mihalnak negÿuen napÿat... }\end{array}$ & VirgK. 33 \\
\hline \multicolumn{3}{|l|}{ Müfaj megjelölése: } \\
\hline $\begin{array}{l}\text { Historia } \quad \text { Nota } \\
\text { diligenj }\end{array}$ & $\begin{array}{l}\text { ānakokaert vg mōd az alamisnas scent Ianus az o } \\
\text { eletiben... }\end{array}$ & SzékK. 244 \\
\hline Explicatio. & $\begin{array}{l}\text {...azert az elso, barat ez vilag kinec te ember } \\
\text { zolgalz... }\end{array}$ & SzékK. 269 \\
\hline \multicolumn{3}{|c|}{ Szövegszakasz kezdetének jelzése: } \\
\hline Hic incipitur & $\begin{array}{l}\text { Dauid en azt mondam ur } \\
\text { Istennec... }\end{array}$ & DebrK. 356 \\
\hline $\begin{array}{l}\text { Incipit de uita } \\
\text { Patris S Francisci }\end{array}$ & $\begin{array}{l}\text { [F]Elseges istennek zolgaÿa es baratÿa ferencz } \\
\text { tamada assisnak varosabol... }\end{array}$ & VirgK. 99 \\
\hline \multicolumn{3}{|l|}{ Magyarázat: $^{3}$} \\
\hline Kalugerek [...] & ... a kalugier baratok kibọl nagi sokan... & DebrK. 105 \\
\hline \multicolumn{3}{|c|}{ Szövegrész latin fordítása: } \\
\hline $\begin{array}{l}\text { Bonu[m] est ab } \\
\text { [ado]lescen[tia] } \\
\text { iugum [Do]mini } \\
\text { [por]tar[e] }\end{array}$ & $\begin{array}{l}\text { O melí ígen io / a fírfÿuí elkẃlLẃnekh mikoron } \\
\text { Ifÿusagatol fogua / viseldi urnak igaiat... }\end{array}$ & DebrK. 13 \\
\hline $\begin{array}{l}\text { [Qui]s diligit } \\
\text { me }[\mathrm{m}] \text { eum } \\
\text { sermo[nem servat] }\end{array}$ & $\begin{array}{l}\text {...ha valaki engomet zeret / meg tartia az en } \\
\text { paranLolatimat... }\end{array}$ & DebrK. 46 \\
\hline
\end{tabular}

Szintén a szövegek egyes elemeinek kiemelésére szolgálnak az a láh ú zá s ok, N B - m e gj e gy zés ek és a manikulák. Figyelemfelkeltésre szolgáló aláhúzásokkal leggyakrabban a SzékK. és DebrK. szövegeiben találkozunk. Ezek gyakran kiegészülnek azzal a latin és tudósi gyakorlatra visszamenő megoldással, hogy a fontos helyeket az olvasók a Nota bene 'jól jegyezd meg' mondattal,

\footnotetext{
${ }^{3}$ A példa idetartozása - és így a kategória létjogosultsága - a nehéz olvashatóság miatt nem kétségtelen.
} 
majd ennek $N B$ rövidítésével jelölik meg a margón. A kódexekben erre viszonylag sok példát találunk, esetlegesen a CornK.-ben (114v) és a DebrK.-ben (175), valamint rendszeresebben a KeszthK.-ben (15, 319), SzékK.-ben (235-276) és a NagyszK.-ben $(25,54,90 \mathrm{stb}$.). A nota bene grafikus megfelelöje a kis mutató kéz, amely a 12. század óta része a kéziratoknak, majd később a nyomtatott könyveknek, plakátoknak, digitális szövegeknek is (bővebben 1. SHERMAN 2008: 25-51). SHERMAN a latin 'kis kéz' jelentésü manicule szót ülteti át az angolba, amely magyarul is használható manikula formában. A kódexekben egyébként a scriptoroktól maradt fenn több manikula, a későbbi bejegyzők között egyetlen esetet találunk: valaki egy imadefiníciót aláhúzással jelöl, majd a margóra írt Def. Orat: marginálist egy kis kéz rajzával is megtámogatja (VitkK. 4).

4.4. Az olvasási élmény kommentálása során keletkezett megjegyzések. Ezeken a bejegyzéseken keresztül ragadható meg legkönnyebben a korabeli olvasási élmény és a szövegekre adott, sokszor egyéni reakció. A beírások arra utalnak, hogyan történt a befogadás, mi volt érdekes a korabeli olvasóknak, információkat tartalmazhatnak a kódexek útjáról, vagy akár tudománytörténeti kérdéseket is felvetnek.

a) Gyakoriak az összefoglalóan érzelmi reflex i ónak nevezhető bejegyzések. Ezek egy-egy lelkiállapot kifejezését vagy valamilyen véleményt tartalmaznak, a bejegyzők pedig vagy azonosulnak a szöveggel, vagy éppen elhatárolódnak tőle. A világ pusztulásáról szóló tanulságokat és okokat elemző szakasznál a lap aljára egy olvasó például a következőt írja: enedes Istennem mel somoru za [!] en lelkem (ErdyK. 17), vagy egy minden bizonnyal protestáns olvasó a tizenhárom bünbocsánatot hozó mise mellé odaírja, hogy Ezek heába valo szók (GömK. 10). A kötetről való véleményét foglalja össze az Apor-kódex valószínüleg 19. századi olvasója: Jedzés A Regiséget tekintö Okoskodások igen Szépek és mélto a meg Tekintésre, De Elemben Bajos az olvasása mend örökke Ammen (AporK. 228). A kategória sajátos példája, amikor az olvasó a saját nevét helyettesíti be az ima megfelelő helyére. Erre egyetlen példát ismerünk: a KeszthK. 449. lapjának az aljára a sarkan bernalnak név van írva (a megfelelő ragos alakban), amellyel a bejegyző az imát magára aktualizálja: „Isten kytwl zenth kewansagok ÿgaz tanachoth ees ÿgaz mywelkedetek vannak agyad the zolgaydnak az bekesegeth kyth ez wylaag nem atath". Határesetet képez egy imakérés, amely a 16. században lezárult kódex üres lapjaira a 17. században imákat bejegyző kéztől származik. Ö a scriptorok jól ismert kérését is az imádság után írja (esetleg aktualizálva másolja): imagi eretem edes leaniom ivstina hogi isten bochasa meg bünemet mongi minden nap chak egi ave mariat eretem (ThewrK. 126).

b) Az érzelmi reflexiók közeli rokonai az erkölcsi megjegyzés e k, amelyek valamilyen erkölcsi mozzanatot, ítéletet is tartalmaznak; például: Mas ä̈andec nem adatik az büneös embernek az az zent leleknek ä̈andeka. [..] kiualkeppen ha ugiā binebeöl megh tisztulni semmi utō modonem akar (DebrK. 390); Minden ember az emaga zemeben neze meg az gerenddat az utan pizkalia az maseban az zalkat (ÉrsK. 362).

c) Más szintü, de még mindig egyfajta olvasási élmény lenyomatai a tu d ó s m e gj e g y z é s e k, amelyek alapvetően a 19. századból maradtak ránk, de van néhány korai, 18. századi példa is: Szent Ferencz Apiainak neue volt Peterfy Bernard (VirgK. 22), az ,...Egÿebet nem Monthatūk hanem czak Az zenth agoston̄ak 
mondasat hol ezt mongya..." mellett álló Istenis azt mondgÿa Hier. 48. (ÉrsK. 163). Továbbiak: NB. A'Cserkesz beszédmód és eme Ortographia között van némi rokonság (VirgK. hátsó kötéstábla); Jegyzés, felülröl az 5d sorban áll: halottaknec, mint Latiatucban: halalnec. Budán, Január 10. 1838. DGábor mk (NagyszK. 258).

4.5. A kézirat vagy annak tartalma előidézte, de ahhoz csak lazán kapcsolódó bejegyzések. E kategória példái általában hosszabb bejegyzések, emiatt tipikus előfordulási helyük nem a margó, hanem az egyéb üresen hagyott helyek: féllapok, lapok, előzéklapok, kötéstáblák. Ezeken a helyeken a föszöveg - direkten - nem vonzza a megnyilvánulásokat, sokkal inkább egy-egy holisztikus véleményt vagy a tárgyhoz nem is kapcsolódó gondolatot rögzítenek a bejegyzők.

a) Ide tartoznak mindenféle ver s ré s z l e t s z e rü b e j e g y zé s e k, a különböző világi költemény-, illetve a zsoltárrészletek. Például: Oh ti Boldog órák hova tuntetek hogy olyan meszszire távoztok a békességes türéstól (AporK. 188); sveuem lolköm viragom czinigem araniom gombom agom leuelem (WeszprK. 108-109); zsoltárrészlet latinul: Dixit Dominus Domino meo Sede adextris meis Donec ponam inimicos tuos Scabellum pedum tuorum (PeerK. 356).

b) Hasonlóan ide vonhatók az egyházi tekintélytől vett idé-

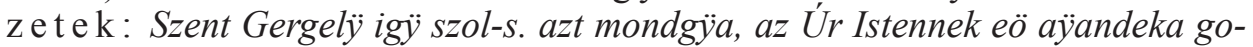
noszoknak nem adatik, migh eök az gonoszsagokba lakoznak. 1640. 13. Januar (DebrK. 391); Egészvilági boldogságoknál boldogságosb, az lölki dolgokban egyedül foglalatoskodnyi; igy irta meg Eugenius P. (KazK. 203).

c) JACKSON tipológiája alapján hagyományosnak mondható múfaj az a já n lá s, amikor az olvasók-tulajdonosok a könyvek elejében vagy végében összefoglalják a könyv tartalmát, vagy ajánlják azt a következő olvasónak. Például: Walamelÿ kereztÿē aÿtatos lelek ez szent es ẃwdueösseges keönyuet gyakorlatossaggal oluassa es ebben Irt wd ẅeözsegre ūalo zep peldakatt megh tartand'a ketsegnelkẅl mind Itt ez Vilagō s mind az öreök Vilagō io lezen dolga (DebrK. 631); Praeambulum / Nékem kedvés olvaso barátom Kérlék hogy né neheszteld jol mégh vigiázni minemü okok legienek ebben az kis maradék könyveczkeben megh Irván és azokat né is olvasd negligenter hanem piae. Néis itild azokat fictiok[na]k mért ha az Sz-Irast jol mégh olvasandod Tehát bö ez igenis bö s télé ézekkel azokkal és még cselekkedvén bizonyos légy rolla hogy mégh ném czalatkozol [...] (KrizaK. elözék); Anno 1689 Die 27 DeCembris Adom Szent Prophessioia Napian Ezta kónÿuet Soror Catharina Franciska Vlassichnak Emlekezettól hogi Sorgalmatossan tanullia Oluasnÿ Sor Maria Victoria Balassa Ordinis S: Clarae. (LányiK. elózéklap).

d) A fig y e $1 \mathrm{~m}$ e z t e té s az előbbihez hasonlóan régi hagyományokra viszszamenő típus. A könyvátkokkal rokon, amelyeket a lopni szándékozók elrettentésére írtak a könyvek elejébe (vö. DROGIN 1983). Az anyag példái a kolostori (valószínűleg klarissza) használat nyomai: Ez akönÿu Mienk Sr Maria Victoriä̈. Szenki el ne uegie. Mert Penteki Imadcsagimot el kel hadnom és biszonial annak alelkin uan aki el ueszi es meg nem agia aki Elö ueszi helire tegie hogi bönt Ne ualiak miata (CzechK. 42); Az Giermekek hazaban valo köniu Az pokolrúl es az ü kinairul [...] Senki el ne vegie az ki el veszi megh agia (GuaryK. hátsó kötés).

e) A vallásos, ájtatos használat nyomai a hosszabb-rövidebb fohás zok, amelyek lehetnek kötött vagy kevésbé kötött szövegek: o orọk isten leǵ ÿrgalmas 
enekem az te zent fÿadnak erdemeert:- leg' ÿrgalmas nekem a: te zenth fÿadert hog wduozwlhesswk (DebrK. 343), Fiat uolluntas tua-. (KazK. 204); I[.]wezleegy: kegy:elmes [...] (GömK. 103). Szerepelhetnek fohász funkcióban esetenként Isten, Jézus, Mária vagy szentek nevei, általában egyes szövegegységek előtt és általában a lapok tetején. A csoport jellemző a scriptorokra is, így a későbbi bejegyzőkre gyakorolt hatásuk vizsgálandó. Példák: Domine Deus (DöbrK. 1); Ihus maria Sctāa Anna (KazK. 171).

f) Bizonyos bejegyzők a kódexek üresen hagyott lapjaira számukra fontos szövegeket másoltak be. A papír drága volt, a kötetek vegyes tematikája viszont láthatóan megszokott dolog volt. Így kerülhetett - valószínúleg a 16. században - a Festetics-kódexbe a János evangéliumának eleje (FestK. 414-416), a Kazinczy-kódex lapjaira a Tízparancsolat (KazK. 166-170), vagy hosszabb imák, amelyekkel a bejegyzők a kódexek eredeti szövegeit egészítették ki (pl. DebrK. 558, ThewrK. elözék, 104, WeszprK. 113).

4.6. A szövegek tartalmától független bejegyzések. Nagyon sok esetben a margók, üres lapok tulajdonképpen jegyzetlap funkciót töltenek be. Ezek a megjegyzések még egyedibbek, esetlegesebbek lehetnek, mint a szöveghez lazábban, de mégis csak kapcsolódó bejegyzések. Arányaiban ebben a csoportban szerepel a legtöbb latin nyelven bejegyzett szöveg. Mivel a felosztás szempontjai a tartalom és funkció mentén alakulnak, ezeket besorolom a magyar nyelvü bejegyzések közé, de fontosnak tartom létezésüket megemlíteni, mert másfajta minőséget, müveltséget tükröznek.

a) Két kódexben találjuk nyomát annak, hogy több személy valamilyen j o g $\mathrm{i}$ e s e m é n y t rögzített. Hasonló ez ahhoz, amikor születési és halálozási vagy más fontos adatokat jegyeznek fel Bibliákba. Példák: Szegöttem megh az én szolgamual Istuan Deakkal ez esztendöben 1618. Sz. keresztnek föl emelesse elöt ualo szerdan,

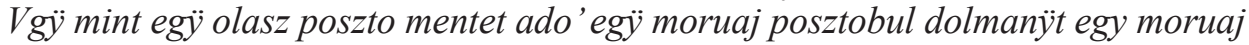
karasia nadrag 2 ümög, 2 gattÿa öuet, 1 czepelöst a mennyit el szagatthat esztendö altal (NagyszK. kötés); Anno Domini 1659 die 28 Martij volt nalō Fecz Balint úr, az Gülesbül jöt hozzā kontora kért hogy szerezzek ha lehet [...] (DebrK. 343); Johannes Kemen Quitavit in festo Marie Magdalene die 22 Julj 1635 (DebrK. 366).

b) Nem jogi, inkább históriai jelentősége van egyes megjegyzéseknek, amelyek történ é s e ket jegyeznek fel; a példában a köz- és magánügyek egymás mellé helyezése látható: Anno Domini 1661 Eztendöben Alih Bassa puztita Erdelt tüzzel vassal. Enis akkor temetem el Havasba' a szovata vize mellett az en edes felesegemet Bala margitot kis aszonj napian ki helben [...] (DebrK. 632).

c) Bizonytalan kategória az üzenet, mert egyetlen példája nehezen olvasható, de a marginális a mondat állítmánya miatt kommunikációs szempontból külön kategóriának tünik: [Min]dazon altal üzènèk nèked Batia Bacia-halgas ra [...] kostolt [...] megh jo[.] hamarsaggal mar szin [...] (DebrK. 16).

d) Pár esetben s zá mítá s o knak tünő számsorokkal találkozunk, amikor egyértelmüen kéznél lévő papír funkciót tölt be a könyv. (Példák: LázK. kötés, PeerK. 356.)

e) To 11 p ró b á knak hagyományosan azokat a tollvonásokat, betüformákat, rövid mondatokat nevezzük, amelyeket a scriptorok azért írtak, hogy a frissen tintába mártott tollról közben lefolyjon a felesleg. A későbbi bejegyzők esetében ezek 
inkább „tollpróbálgatások” vagy „örömírás”; olyan bejegyzések, amelyek nem információ közlése miatt születnek, csak szó szerint próbálgatják a tollat - a kutató számára mégis rengeteg információt hordozhatnak. Ilyenek az iniciálék átmásolásai (SzékK. 163, PeerK. 351); a nagy, kacskaringós betúkkel írt, be nem fejezett mondatok (SzékK. 132, 322) vagy egy-egy betü, esetleg az ábécé sokszori leírása (CornK. 208r, LázK. kötés, SzékK. 29). Adott esetben bizonyos szövegeknél nehéz eldönteni, hogy tollpróbáról vagy tartalmas bejegyzésről van-e szó, például a levélkezdő formula (CornK. 2r, DebrK. 248, PozsK. 80), fohászok vagy nevek esetében. Azok a bejegyzések kerültek ebbe a kategóriába, amelyeket máshogy tényleg nem lehet értelmezni. A tollpróbák, ,intézményesült” szövege és más hasonlók is előfordulnak a kódexek lapjain: Probatio calami (VitkK. 1), probatio atrami et atramet (LázK. 307).

A tollpróbáknak grafikus változatai is lehetnek, egy nagyon vegyes és határeseti csoport, amelyet bizonyos kutatók nem is tekintenek marginálisnak. A látszólagos firkák vagy indokolatlanság mögött azonban esetenként fontos okok állhatnak. Az Érsekújvári kódexben helyenként szereplő keresztek bizonyos szövegek mellett például egy 18. századi apácának, Újfalusi Juditnak a bejegyzései, mert a Makula nélkül való tükör címü népszerü, csehböl fordított müvének a cseh változatban nem szereplő részei megegyeznek a kódex kijelölt szakaszaival (LAUF 2014). A felfedezés jó példa arra, hogy attól, hogy valamit nem értünk, még nem biztos, hogy szándéktalan és esetleges. Ilyen grafikus jelek az ikszek (DebrK. 505, SzékK. 316), keresztek, amelyek valószínủleg sokszor az olvasandó vagy másolandó szakaszok elejét vagy végét jelzik (DebrK. 505; TihK. 84, 85, 296 stb.; WeszprK. 17), valódi firkák (AporK. 198; JókK. első kötés, 142; FestK. 10) és madarak rajzai (ÉrsK. 162, 163; PozsK. 29).

4.7. B es orolhatatlan bejegyzések is találhatók természetesen szép számmal az anyagban, aminek két fő oka a (ki)olvashatatlanság és a törlés. Előbbit okozhatja egyszerủ kopás, olvashatatlan írás vagy a könyvkötők általi (részleges) lemetszés (pl. DebrK. 325, PeerK. 283, SándK. 40, SimK. 2), utóbbiak pedig azt a többletinformációt is hordozzák, hogy valakit annyira zavart az adott marginális, hogy kaparással, mosással vagy egyéb módon teljesen eltüntette (pl. KrizaK. 26, 62, PozsK. 21).

5. Összefoglalás, további célok és kérdések. A vizsgálat nyomán látható egyrészt, hogy az ómagyar kódexek marginálisainak anyaga - habár a korabeli kéziratok fennmaradásának alacsony száma miatt a korpusz igen töredékes - beleillik a nemzetközi hagyományba. Másrészt megállapítható, hogy mint sajátos anyag, nem alkalmazható rá már kész kategorizáció - önálló belső dinamikája, logikája van, és a tárgyból adódóan természetesen egyedi kutatási kérdései. Akár egyetlen marginális vagy marginálisok csoportja vethet fel több, olykor szerteágazó kérdést is, így terveim között szerepel elsősorban a kategorizáció véglegesítése, finomítása, az egyes kódexeknek a kategóriák alapján történő jellemzése, kezek összekapcsolása, - amennyiben lehetséges - azonosítása, időben jellemző tendenciák feltárása, majd esettanulmányok készítése egyes kódexekről, problémákról. Ilyenek többek között az említett „klarissza kéz”, a Virginia-kódex lapszéli szavai, amelyeket esetleg a Nyelvtörténeti szótár anyagához „cédulázott ki” valaki a margókra, vagy a nyelvi javítások nyelvtörténeti tanulságai. 
Kulcsszók: ómagyar kódexek, margináliakutatás, olvasói marginálisok, marginálistípusok.

\section{Hivatkozott irodalom}

CAmBers, ANDREw 2010. Readers' Marks and Religous Practice: Margaret Hoby's Marginalia. In: KING, JoHN N. ed., Tudor Books and Readers. Materiality and the Construction of Meaning. Cambridge University Press, New York. 211-231.

COPELAND, Rita 1991. Rhetoric, Hermeneutics, and Translation in the Middle Ages: Academic Traditions and Vernacular Texts. Cambridge Studies in Medieval Literature 11. Cambridge University Press, Cambridge. http://doi.org/10.1017/CBO9780511597534

Drogin, MARC 1983. Anathema! Medieval Scribes and the History of Book Curses. Allanheld \& Schram, Totowa.

DufFY, EAMON 2006. Marking the Hours. English People and Their Prayers. 1240-1570. Yale University Press, New Haven - London. http://dx.doi.org/10.3366/more.2008.45.2.13

Grindley, CARL JAmes 2001. Reading Piers Plowman C-Text Annotations: Notes Toward the Classification of Printed and Written Marginalia in Texts from the British Isles 1300-1461. In: KerBy-Fulton, KATHRYN - HILMO, MAIDIE eds., The Medieval Professional Reader at Work: Evidence from Manuscripts of Chaucer, Langland, Kempe and Gower. English Literary Studies, University of Victoria, Victoria. 77-91.

HAADER LEA 2005. A nyelvi (ízlés)változás nyomai az Érsekújvári kódexben. In: MÁRTONFI ATTILA - PAPP KoRNÉliA - SLÍz MARIANN szerk., 101 irás Pusztai Ferenc tiszteletére. Argumentum, Budapest. 103-109.

HAADER LEA 2009. Én édes Istenem, segíts engemet erre az könyvre! A kódexek tanúságaiból. In: KOROMPAY KLÁRA - TERBE ERIKA - C. VLADÁR ZSUZSA - ZSILINSZKY ÉVA szerk., Forráskutatás, forráskiadás, tudománytörténet. A Magyar Nyelvtudományi Társaság Kiadványai 229. Magyar Nyelvtudományi Társaság, Budapest. 35-47.

JaCKSON, HEATHER J. 2001. Marginalia. Readers Writing in Books. Yale University Press, New Haven - London.

Kerby-Fulton, Kathryn 1999. The Professional Reader as Annotator. In: KerbyFulton, KATHRYN - Despres, Denise L. eds., Iconography and the Professional Reader. The Politics of Book Production in the Douce Piers Plowman. Medieval Cultures 15. University of Minnesota Press, Minneapolis-London. 68-91.

Kerby-Fulton, KathrYN 2012. Professional Readers at Work. Annotators, Editors and Correctors in Middle English Literary Texts. In: KerbY-Fulton, KATHRYN Hilmo, MAide - Olson, LindA eds., Opening Up Middle English Manuscripts. Literary and Visual Approaches. Cornell University Press, Ithaca-London. 207-244.

P. KoCSIS RÉKA 2015. Mikor íródtak az Apor-kódex marginális bejegyzései? In: P. KOCSIS RÉKA - SZENTGYÖRGYI RUDOLF szerk., Anyanyelvünk évszázadai 1. Az ELTE Benkö Loránd Nyelvtörténeti Hallgatói Mühelye által szervezett 2014. június 20-i nyelvtörténeti konferencia elöadásaiból készült tanulmánykötet. ELTE Magyar Nyelvtörténeti, Szociolingvisztikai, Dialektológiai Tanszék, Budapest. 21-27.

P. KoCSIS RÉKA 2016. Az Apor-kódex és Székely István „Zsoltárkönyv”-ének zsoltárcímei. In: KoCsis ZsuZsANNA - NÉMETH LuCA ANNA - TAKÁCs EDIT szerk., Talál- 
kozások Félúton: Az Eötvös Loránd Tudományegyetem Nyelvtudományi Doktori Iskolájának 10. Félúton konferenciáján elhangzott elöadások tanulmánykötete. ELTE Magyar Nyelvtudományi és Finnugor Intézet, Budapest. 105-122.

P. KOCSIS RÉKA megj. e. Elméleti és gyakorlati szempontok a marginálisok vizsgálatához. In: FAZEKAS BOGLÁRKA - KAPOSI DiÁNA - P. KoCsis RÉKA szerk., Félúton 12. Az ELTE Nyelvtudományi Doktori Iskolájának 2016. október 6-7-i konferenciáján elhangzott elöadások. Kiadja az ELTE BTK Magyar Nyelvtudományi és Finnugor Intézete, Budapest. (Megjelenés előtt.)

LAUF JUDIT 2014. Az Érsekújvári kódex és a Makula nélkül való tükör. A középkori magyar passióhagyomány nyomai a 18. századi kegyességi irodalomban. Magyar Könyvszemle 130: 218-236.

LÁzS SÁNDOR 1981. A Cornides-kódex körül. Irodalomtörténeti Közlemények 85: 671-683. PuSZTAI ISTVÁN - MADAS EDIT 1994. Bevezetés. In: Nádor-kódex 1508. A nyelvemlék hasonmása és betühü átirata bevezetéssel és jegyzetekkel. Közzéteszi: PUSZTAI ISTVÁN. Régi Magyar Kódexek 16. Magyar Nyelvtudományi Társaság, Budapest. 7-23.

ROSENTHAL, BERnARD M. 1997. The Rosenthal collection of printed books with manuscript annotations: a catalog of 242 editions mostly before 1600, annotated by contemporary or near-contemporary readers. Beinecke Rare Book and Manuscript Library - Yale University Press, New Haven.

Rosenthal, Bernard M. 1998. Cataloging Manuscript Annotations in Printed Books. Some Thoughts and Suggestions from the Other Side of the Academic Fence. La Bibliofilía 100: 583-595.

Sherman, William H. 2008. Used Books. Marking Readers in Renaissance England. University of Pennsylvania Press, Philadelphia.

STODDARD, Roger E. 1985. Marks in Books, Illustrated and Explaned. Houghton Library, Harvard University, Cambridge (MA).

Tanselle, Thomas G. 2011. Other People's Books: Association Copies and the Story They Tell. Caxton Club, Chicago.

Whitaker, Elaine E. 1994. A Collaboration of Readers. Categorization of the Annotation of Caxton's Royal Book. Text 7: 233-242.

\section{The typology of marginalia in Old Hungarian codices}

The paper examines the marginalia of the 45 surviving codices from the 14-16th centuries written in Old Hungarian, with focus on marginalia left by later users and readers. After a brief overview of the origins and main questions of international research on marginalia the author presents a new typology of the corpus. The six main categories and their subcategories were derived from the contents and functions of the texts. This typology facilitates the exploration of further matters related to marginalia in the Old Hungarian codices, and serves as the basis of an ongoing, broader research.

Keywords: Old Hungarian codices, research of marginalia, marginalia by readers, typology.

P. KOCSIS RÉKA

Eötvös Loránd Tudományegyetem 